\title{
MADRASAH SEBAGAI SEKOLAH ISLAMI DAN PELAKSANA PENDIDIKAN INKLUSI
}

\author{
Ahmad Abtokhi \\ Dosen pada program studi Fisika dan PGMI UIN Malang
}

\begin{abstract}
The goal of this paper was to study critically why madrasah as an institutional development agen of Islamic education in Indonesia, whith the innovation is that of curriculum oriented in hospitality in approaching the students based on tauhid (the unity of science and religion). The study is carried out in the prespective of Islamic education concept and that of inclusive education.

Through comparative analysis, the study finds five same characteristics of Islamic education and inclusive education: (1) education as a right or duty; (2) education for all; (3) the principle of non-segregation; (4) the holistic view of the pupil; (5) handicap seen in relation to external factors, especially school environment.

Madrasah can be viewed as an application of both the principle of non-segregation and the holistic view of the pupil. The principle of non-segregation is applicated in the process of education with the hospitality to all students: everyone is admitted in accordance with his faculty and potentiality, and receives educational services without discrimination. Moreover, the holistic view of the pupil is applicated in the intended design to meet the faculty of reasoning with that of intuition in the process of learning by the integration the revealed signs from the Qur'an and Sunnah with the cosmic signs (matters of natural and social sciences). The innovation, then, has made the revealed signs the first data as well as the source of values-both are marginalized in the contemporary practice of education.

Other principles are being challenges the madrasah should anticipate in the future. One of them is the developing education human resource, and the way of student recruitment, because they have deferent background.
\end{abstract}

Keyword: Madrasah, Islamic, Inclusion Education

\section{A. Pendahuluan}

Madrasah merupakan lembaga pendidikan yang berada di bawah Departemen Agama, namun kurikulum pembelajarannya mengikuti Departemen Pendidikan Nasional. Berdasarkan Peraturan Pemerintah Nomor 28 dan nomor 29 tahun 1990 tentang Pendidikan Dasar dan Menengah, serta diberlakukannya kurikulum tahun 1994, Madrasah 
berubah statusnya menjadi sekolah umum yang bercirikan khas Islam (Khoiri, 2004). Meskipun disebut sekolah umum yang bercirikan Islam, madrasah masih terus mencari bentuk idealnya. Dalam menghadapi abad 21, pembenahan madrasah sepatutnya diawali dengan niat dan tekad untuk mewujudkan madrasah sebagai "Madrasah sebagai sekolah islami yang benar-benar islami" yang mampu memadukan kekuatan Ilmu Pengetahuan dan Teknologi (IPTEK) dan Iman dan Takwa (IMTAK), antara daya pikir dan dzikir, bukan hanya sebagai jargon belaka, akan tetapi nilai lebih dari madrasah yang terletak pada pendidikan keimanan yang menekankan pada kepekaan hati dan ketajaman akal dapat terealisasikan.

Seiring dengan gema kebangkitan pendidikan Islam, pada tataran global berkembang tuntutan perlunya kesempatan pendidikan yang merata kepada semua manusia, tanpa membedakan kemampuan fisik (normal atau tuna), strata sosial, jender, dan latar belakang etnis, budaya dan agamanya. Tuntutan global ini telah melahirkan sebuah deklarasi dunia yang dikenal dengan Education for All (1990) (UNESCO, 1990). Aplikasi dari deklarasi tersebut telah melahirkan kesadaran akan 'Pendidikan Inklusi' yang dinyatakan secara eksplisit dalam Salamanca Statement and Framework for Action, produk World Conference on Special Needs Education (Salamanca, Spanyol, 1994) (UNESCO, 1994), dan kemudian diperteguh dalam Dakar Framework for Action, produk World Education Forum (Dakar, Senegal, 2000) (UNESCO, 2003).

Atas dasar asumsi bahwa madrasah sebagai sekolah islami yang dimaksudkan untuk menjelaskan bahwa lembaga pendidikan yang mendasarkan segenap kegiatannya atas pandangan dan nilai-nilai Islam dan sekaligus mensosialisasikannya, bukan sebatas menghasilkan lulusan yang hanya menguasai ahli dibidang ilmu-ilmu agama saja, seperti: Fiqh, Tauhid, Tajwid, dan yang lain. Tulisan ini mencoba mengelaborasi konseptualisasi pendidikan Islam untuk dijadikan basis sekolah islami, dan kemudian dikaitkan dengan isu global pendidikan inklusi.

\section{B. Konseptualisasi Pendidikan Islam sebagai Dasar dalam Pengembangan Madrasah sebagai Sekolah Islami}

Konseptualisasi di sini dilakukan dengan dua pendekatan, yaitu pendekatan filosofis-normatif dan pendekatan historis-linguistik. Pendekatan pertama digunakan untuk mencari apa itu hakekat manusia dengan bertolak dari norma-norma Qur'ani, sementara pendekatan terakhir digunakan untuk mencari bagaimana tradisi Muslim dalam mengembangkan pendidikannya terutama di era klasik, termasuk penggunaan kata-kata kunci yang terkait dengan pendidikan Islam dalam tradisi Muslim tersebut. Produk kajian dari dua pendekatan tersebut kemudian dijadikan dasar bagi perumusan konsep pendidikan Islam yang dijadikan dasar dalam pengembangan madrasah sebagai sekolah islami. 


\section{Hakekat Manusia}

Banyak cara dipakai untuk menjelaskan hakekat manusia, namun dalam tulisan ini lebih terfokus pada 'sesuatu yang amat vital yang menentukan hidup manusia,' baik di tengah masyarakat maupun di mata Allah SWT. Dengan mengkaji pesan-pesan Al-Qur'an, sesuatu yang amat vital yang menentukan hidup manusia itu tidak lain adalah amalnya yang mencakup gagasan, perbuatan dan karya. Sebagaimana firman Allah pada beberapa ayat Al-Qur'an berikut:

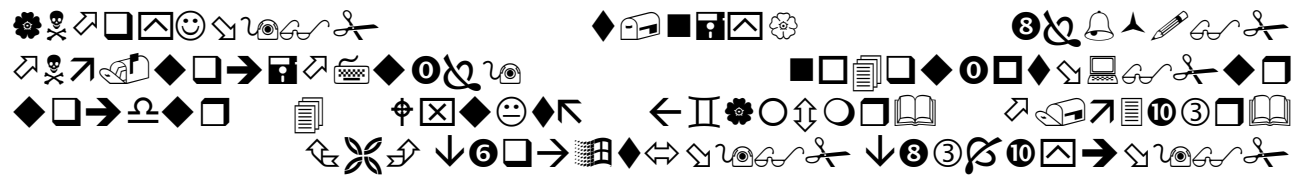

Yang menjadikan mati dan hidup, supaya dia menguji kamu, siapa di antara kamu yang lebih baik amalnya. dan dia Maha Perkasa lagi Maha Pengampun, [Q.S. Al-Mulk (67): 2]

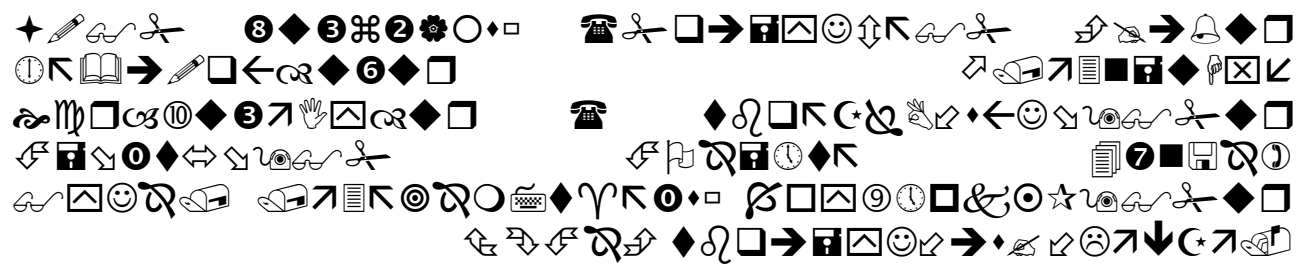

Dan Katakanlah: "Bekerjalah kamu, Maka Allah dan rasul-Nya serta orangorang mukmin akan melihat pekerjaanmu itu, dan kamu akan dikembalikan kepada (Allah) yang mengetahui akan yang ghaib dan yang nyata, lalu diberitakan-Nya kepada kamu apa yang Telah kamu kerjakan. [Q.S. AtTaubah (9): 105]

sebagai wujud penjelmaan kepribadiannya yang dikembangkan melalui pelatihan potensi-potensinya, sebagaimana ayat berikut:

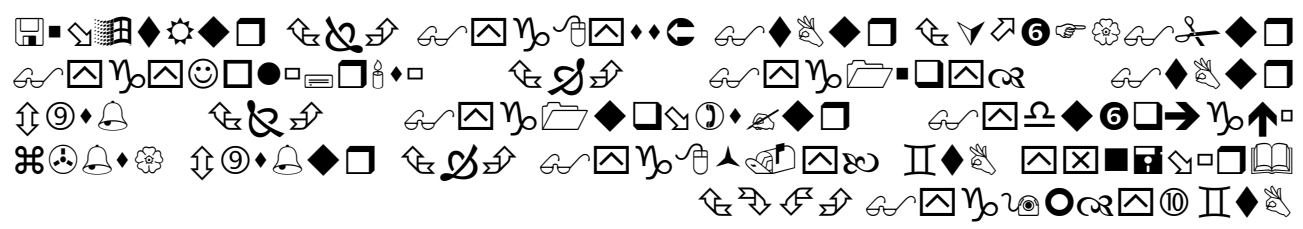

Dan bumi serta penghamparannya, Dan jiwa serta penyempurnaannya (ciptaannya), Maka Allah mengilhamkan kepada jiwa itu (jalan) kefasikan dan ketakwaannya. Sesungguhnya beruntunglah orang yang mensucikan jiwa itu, Dan Sesungguhnya merugilah orang yang mengotorinya. [Q.S. Asy-Syams (91): 7-10]

melaksanakan mandatnya, baik sebagai hamba Allah maupun sebagai khalifah-Nya. Berikut ayat Al-Qur'an yang berkaitan tentang hal tersebut, 


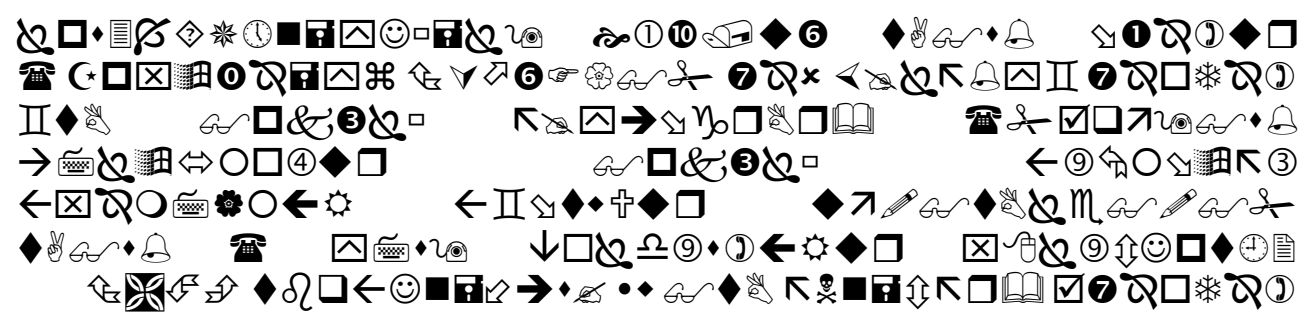

Ingatlah ketika Tuhanmu berfirman kepada para malaikat: "Sesungguhnya Aku hendak menjadikan seorang khalifah di muka bumi." mereka berkata: "Mengapa Engkau hendak menjadikan (khalifah) di bumi itu orang yang akan membuat kerusakan padanya dan menumpahkan darah, padahal kami senantiasa bertasbih dengan memuji Engkau dan mensucikan Engkau?" Tuhan berfirman: "Sesungguhnya Aku mengetahui apa yang tidak kamu ketahui." [Q.S. Al-Baqarah (2): 30]

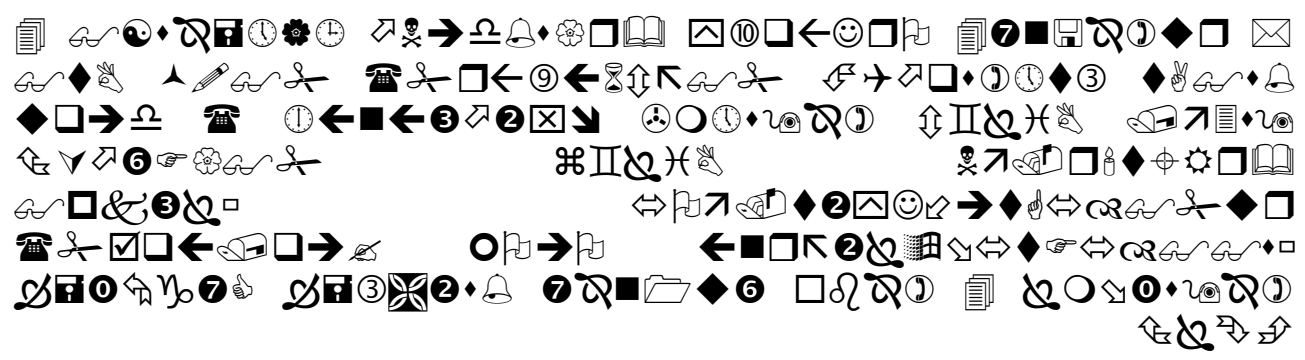

Dan kepada Tsamud (Kami utus) saudara mereka shaleh. Shaleh berkata: "Hai kaumku, sembahlah Allah, sekali-kali tidak ada bagimu Tuhan selain Dia. dia Telah menciptakan kamu dari bumi (tanah) dan menjadikan kamu pemakmurnya[*], Karena itu mohonlah ampunan-Nya, Kemudian bertobatlah kepada-Nya, Sesungguhnya Tuhanku amat dekat (rahmat-Nya) lagi memperkenankan (doa hamba-Nya)." [Q.S. Hûd (11): 61]

[*] Maksudnya: manusia dijadikan penghuni dunia untuk menguasai dan memakmurkan dunia.

\section{Pendidikan dalam Tradisi Muslim Klasik}

Pendidikan adalah kewajiban pertama seorang Muslim, baik lakilaki maupun perempuan. Pengetahuan Tuhan diasosiasikan dengan proses belajar dan mengajar sebagaimana digambarkan dalam Al-Qur'an surat Al'Alaq (96) ayat 1-5 berikut,

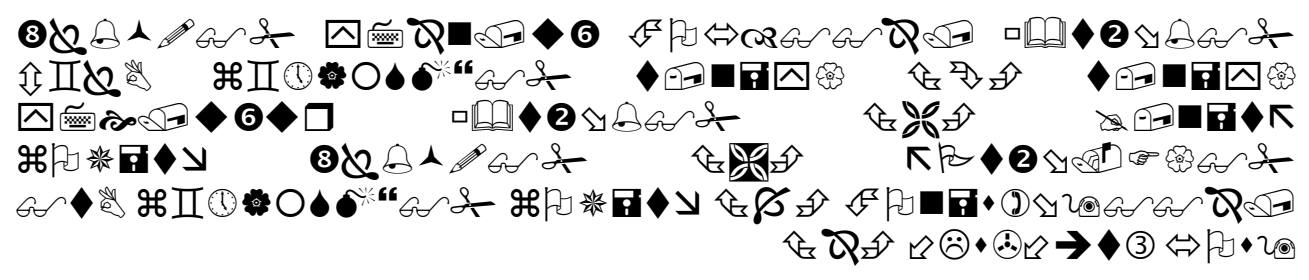

Bacalah dengan (menyebut) nama Tuhanmu yang Menciptakan, Dia Telah 
menciptakan manusia dari segumpal darah. Bacalah, dan Tuhanmulah yang Maha pemurah, Yang mengajar (manusia) dengan perantaran kalam[**], Dia mengajar kepada manusia apa yang tidak diketahuinya.

[**] Maksudnya: Allah mengajar manusia dengan perantaraan tulis baca.

Proses pendokumentasian secara baik teks-teks Islam (terutama AlQur'an dan As-Sunnah) memperlihatkan kemunculan awal 'tradisi melek huruf' dan pewarisannya di antara sesama Muslim sebagai sebuah prioritas sosial. Telah menjadi tradisi kuat dalam masyarakat Muslim sejak awalnya untuk membaca, menulis dan menghafal firman-firman Allah SWT dan hadis-hadis Rasulullah SAW. Ilmu-ilmu tentang Al-Qur'an dan penafsirannya dan ilmu-ilmu tentang Hadis berikut kritik sanad dan matannya (otentisitas perawi dan subtansi hadis) kemudian menjadi fondasi bagi keahlian dalam berbagai disiplin ilmu, terutama hukum Islam (Douglass dan Shaikh, 2004).

Menjelang periode kekhalifahan Abbasiyah awal, tradisi melek huruf telah menjadi mapan dalam berbagai macam bidang studi. Penulisan sejarah menjadi menonjol untuk mencatat peristiwa-peristiwa penting dalam perkembangan awal Islam. Wilayah-wilayah baru Islam umumnya memiliki komitmen pertamanya pada penulisan, dan kemunculan 'sejarah universal' telah mensintesiskan banyak pengetahuan Yunani Klasik dan peradaban India dan Persia (Duri, 1983). Kemanusiaan berkembang dengan berkembangnya peradaban Islam. Sains telah berkembang di atas landasan pengetahuan praktis komunitas Muslim dalam pelayaran, navigasi, astronomi, perdagangan, peternakan dan pertanian. Perkembangan hukum Islam telah memotivasi pembuatan penunjuk waktu dan kalender yang baku, arah kiblat yang akurat, dan kalkulasi yang tepat dalam warisan, timbangan dan pengukuran. Rasa ingin tahu yang besar, akses geografis yang mudah dan fasilitas yang memadai termasuk suplai dana dari khalifah dan wakaf dari umat telah mendorong dinamika penerjemahan, penyerapan, pengembangan dan penyebaran pengetahuan dalam berbagai bidang secara masif (Hassan dan Hill, 1986). Kedatangan teknologi pembuatan kertas dari Cina telah memberikan daya dorong tambahan pada dinamika tersebut (Sardar dan Malik, 1997).

Tumbuh-kembangnya tradisi melek huruf ini telah mengakibatkan pembentukan institusi-institusi pendidikan yang memajukan gagasan tentang pendidikan Islam, seperti pemerataan pendidikan atau pendidikan untuk semua untuk konteks kurun saat itu. Dinamika perkembangan ilmu pengetahuan, sebagai bentuk konkret tradisi melek huruf, telah menyumbangkan suatu konsep tentang pendidikan Islam yang menempatkan tidak adanya rintangan antara "belajar yang relijius" dan "belajar yang sekuler". Al-Qur'an sendiri merupakan sumber inspirasi yang kaya bagi banyak bidang ilmu, baik karena anjurannya untuk mencari dan berbagi ilmu maupun karena penjelasannya tentang fenomena 
alam yang sungguh sangat menggugah rasa ingin tahu, sebagaimana firman Allah berikut,

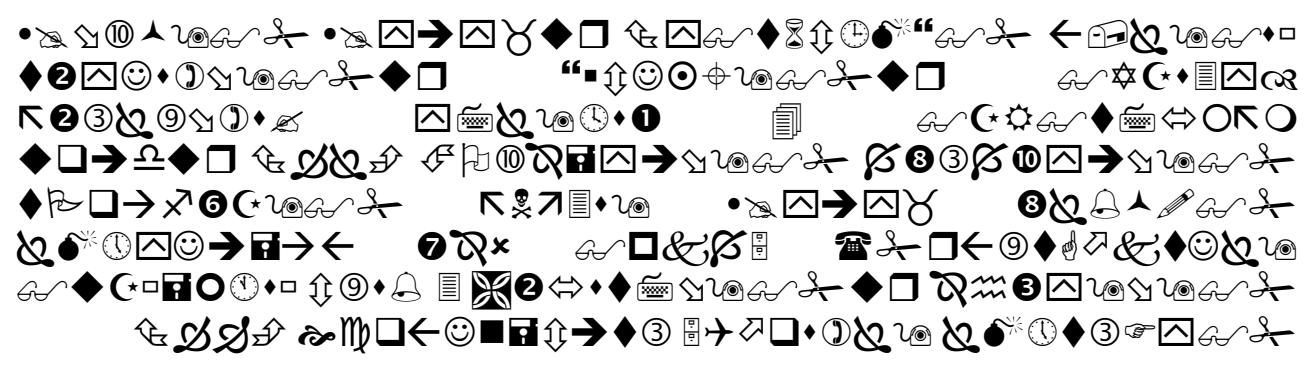

Dia menyingsingkan pagi dan menjadikan malam untuk beristirahat, dan (menjadikan) matahari dan bulan untuk perhitungan. Itulah ketentuan Allah yang Maha Perkasa lagi Maha Mengetahui. Dan dialah yang menjadikan bintang-bintang bagimu, agar kamu menjadikannya petunjuk dalam kegelapan di darat dan di laut. Sesungguhnya kami Telah menjelaskan tanda-tanda kebesaran (kami) kepada orang-orang yang Mengetahui. [AlAn`âm (6): 96-97].

Kata Arab untuk agama, yaitu dîn-Islam disebut sebagai dîn, ternyata memiliki hubungan yang kuat dengan kehidupan yang intelektual dan beradab. Akar kata dîn adalah d-y-n, yang maknanya menekankan hubungan antara kehidupan yang spiritual, intelektual dan beradab. Empat makna pokok dari akar kata tersebut adalah: kewajiban bersama, ketundukan atau pengakuan, kewenangan yudisial dan kecenderungan hati. Dîn mengekspresikan (pemenuhan) kewajiban terhadap Tuhan Yang Esa, berdasarkan kecenderungan hati terhadap Sang Pencipta. Akar kata d$y-n$ juga berkonotasi gagasan tentang hutang, sebuah transaksi yang melibatkan pertukaran kepercayaan dan kewajiban. Kata kota - madinnah berasal dari akar kata yang sama. Kota adalah suatu komunitas dengan relasi dan transaksi sosial yang kompleks, berbasis pada pemenuhan kewajiban secara bertanggung jawab dan timbal balik, dan ketundukan kepada keputusan dan otoritas sipil. Dua basis tersebut mengimplisitkan keadaban. Sedangkan kata peradaban-tamaddun-terkait juga dengan akar kata d-y-n. Kata kerja tamaddana berarti mendirikan kota atau memanusiakan pemikiran, sehingga tamaddun berarti sivilisasi atau pengadaban masyarakat. Dengan demikian, agama dan pendidikan dibawa bersama dalam usaha manusia untuk mengetahui dan mengagungkan Tuhan Pencipta, serta mencari pengetahuan dan menggunakannya untuk kemanfaatan masyarakat. Pengetahuan tersebut dikembangkan dan diwariskan untuk kesinambungan masyarakat yang beradab (Douglass dan Shaikh, 2004).

Dalam tradisi Islam, ada dua kata kunci yang memiliki akar kata yang sama, yaitu `ilm (jamaknya `ulûm, pengetahuan) dan `alîm (jamaknya 
'ulamâ', orang yang mengembangkan dan mewariskan pengetahuan). Dikenal dua klasifikasi pengetahuan yang berasal dari sumber yang sama, Tuhan Sang Pemilik Hazanah Pengetahuan, yaitu'ulûm qauliyah (pengetahuan yang dikembangkan dari fenomena Allah yang terdapat dalam wahyuNya) dan `ulûm kauniyah (pengetahuan yang dikembangkan dari fenomena Allah yang terdapat dalam alam ciptaanNya) (Santoso, 1992). 'Ulamâ' yang perannya tidak hanya sebagai pendidik, namun juga sebagai sarjana dan ahli hukum, menjadi kelompok sosial yang berpengaruh sepanjang sejarah peradaban Muslim dengan menjadi hakim dan dipercaya memimpin yayasan sosial, dan bahkan bila perlu menjadi pengontrol penguasa, di samping sebagai aktor yang memadukan kepercayaan dan praktik Islam dan memelihara tradisi melek huruf dalam masyarakat Muslim (Douglass dan Shaikh, 2004).

Masih ada dua kata kunci tambahan. Pertama, adab yang berarti suatu kebiasaan atau norma perilaku yang diwariskan antar generasi. Seiring dengan perkembangan peradaban Muslim, kata tersebut lalu bermakna 'kualitas kejiwaan yang tinggi, pengasuhan yang baik, kehalusan budi dan kesopanan'. Pada masa Abbasiyah, adab telah diterima sebagai produk pendidikan yang bernilai. Dalam sistem pendidikan, adab menerima pemaknaan intelektualnya, yaitu sejumlah pengetahuan yang membuat seseorang sopan dan halus budinya. Pengetahuan yang dimaksud disajikan melalui retorika, tata bahasa, leksikografi, metrik, puisi, sastra dan sains. Konsep adab, dengan demikian, membantu pengembangan estetik dari kehidupan yang beradab dan menjadi bagian yang integral dari pendidikan dalam spirit Islam. Kedua, tarbiyah yang merujuk pada pendidikan moral, dan berasal dari suatu akar kata r-b-w yang terkait dengan akumulasi. Pendidikan moral disebut tarbiyah karena memerlukan akumulasi latihan dan contoh (Douglass dan Shaikh, 2004).

Penerimaan pengetahuan, etika dan suatu pandangan hidup moral merupakan suatu landasan bagi pencapaian apa yang diminta Allah terhadap setiap manusia untuk melaksanakan apa yang disebut baik dan menghindari apa yang disebut jahat. Pendidikan memberikan seseorang pengetahuan untuk mengenal tugas dan tujuan hidupnya, fondasi moral untuk mengetahui apa yang harus dikerjakan, dan sumber-sumber personal untuk melaksanakan tugas.

Individu-individu yang dididik secara Islam akan mampu mengkombinasikan dan mengintegrasikan aspek-aspek pendidikan Islam yang telah dijelaskan di atas dengan aspek real di dalam kehidupan. Mereka akan benar-benar mengetahui secara baik sumber-sumber orisinal Al-Qur'an dan As-Sunnah sebagaimana juga mengenal secara baik disiplin-disiplin keilmuan. Dalam mempelajari dîn, mereka akan belajar melaksanakan kewajiban-kewajiban iman dan bertindak sesuai dengan prinsip-prinsipnya. Melalui pengajaran etika dan moral, individu yang 
terdidik akan bertindak penuh tanggung jawab secara sosial, menerima penghormatan sosial kehidupan beradab, dan ikut serta dalam menyumbangkan sejumlah ketrampilan dan pengetahuan di masyarakat.

\section{Konsep Pendidikan Islam}

Dengan memahami hakekat manusia dan pendidikan dalam tradisi Muslim seperti diuraikan di atas, dapatlah dirumuskan konsep pendidikan Islam, yaitu proses membantu pertumbuhan dan perkembangan kepribadian manusia secara menyeluruh dan seimbang melalui pelatihan segenap daya dan potensi (termasuk daya dzikir dan nalarnya) yang dilaksanakan sedemikian rupa sehingga nilai-nilai Islam tertanam dalam kepribadiannya dan melahirkan amal dan kebudayaan yang berorientasi kepada nilai-nilai tersebut, sehingga mandatnya sebagai hamba Allah dan khalifah-Nya dapat diaktualisasikan (Cf. al-Attas, 1979; Ashraf, 1985).

Pelatihan dilaksanakan dengan keterpaduan tiga kata kunci ta' lîm, tarbiyah dan ta'dîb. Ta'lîm, yang kata dasarnya 'ilm (telah diuraikan di atas) dan bermakna pembelajaran, dilaksanakan dengan strategi yang sarat dengan cinta dan keramahan namun dapat dipertanggungjawabkan secara akademik. Tarbiyah dilaksanakan dengan penanaman perilaku yang merefleksikan moral dan nilai Islam seperti dijelaskan dalam Al-Qur'an dan As-Sunnah. Ta'dîb, yang kata dasarnya adab (telah diuraikan juga di atas) dan bermakna pengadaban, dilaksanakan dengan membantu peserta didik mengembangkan dimensi estetik dan meraih tujuan-tujuan spiritual melalui pencarian pengetahuan dan pelayanan kepada masyarakat. Akhirnya keterpaduan ta' ${ }^{\prime} i ̂ m$, tarbiyah dan $t a^{\prime}{ }^{\prime} i \hat{b}$ dapat disebut tiga dimensi proses pendidikan Islam yang akan memperkuat spirit penelitian dan pengembangan yang terbuka di mana iman dan nalar mengantarkan peserta didik menuju pengetahuan yang tinggi, kemampuan yang produktif, perilaku bermoral dan estetik, pilihan hidup individual yang logis dan sehat, dan kewarganegaraan yang bertanggung jawab. Dengan demikian, operasionalisasi ta'lîm, tarbiyah dan ta'dîb tidak hanya mengambil bentuk-bentuk formal, namun juga non-formal, dan bahkan informal (Santoso, 1992).

Tiga dimensi proses pendidikan di atas, ta' ${ }^{\prime} \hat{m}$, tarbiyah dan $t a^{\prime}{ }^{\prime} \hat{\imath} b$, secara eksplisit, menyiratkan fungsi-fungsi pendidikan Islam. Pendidikan Islam tidak hanya berfungsi secara internal untuk mengembangkan kepribadian dan mengembangkan kemampuan yang bersifat produktif, tetapi secara eksternal berfungsi juga untuk mengembangkan ilmu dan peradaban. Selain itu, tiga dimensi proses pendidikan di atas menyiratkan juga bagaimana kaitan antara manusia, masyarakat, dan lingkungannya, dan antara ketiganya dengan Allah, dan sebagai konsekuensinya, pendidikan merupakan tanggung jawab individu, keluarga, masyarakat, dan negara. 
Ketika dikaitkan dengan dîn, madînah, dan tamaddun, maka pendidikan dalam perspektif Islam dalam kerangka hubungan yang bersifat vertikal (hubungan manusia dengan Allah) merupakan sesuatu yang bernilai ibadah, bahkan suatu kewajiban prasyarat untuk dapat memahami kewajiban Islam yang lain (fardhu kifayah), dan dalam kerangka hubungan horizontal, hubungan antara sesama manusia dan dengan makhluk lainnya, pendidikan merupakan kewajiban prasyarat untuk membangun kebudayaan atau peradaban sebagai wujud memelihara mandat sebagai khalifahtullah.

\section{Pendidikan Inklusi: Pengenalan Konsep}

Sebagaimana telah dijelaskan di muka, pendidikan inklusi merupakan konsekuensi lanjut dari kebijakan global Education for All (Pendidikan untuk Semua) yang dicanangkan oleh UNESCO 1990. Kebijakan Education for All itu sendiri merupakan upaya untuk mewujudkan hak asasi manusia dalam pendidikan yang dicanangkan dalam Deklarasi Universal Hak-Hak Asasi Manusia 1949. Konsekuensi logis dari hak ini adalah bahwa semua anak memiliki hak untuk menerima pendidikan yang tidak diskriminatif atas dasar hambatan fisik, etnisitas, agama, bahasa, jender dan kecakapan. Pendidikan inklusi yang dideklarasikan dalam Konferensi Dunia tentang Pendidikan untuk (Mereka Yang Membutuhkan) Kebutuhan Khusus di Salamanca, Spanyol, 1994, dan diperteguh dalam Forum Pendidikan Dunia di Dakar, Senegal, 2000, merupakan suatu pendekatan yang berusaha memenuhi kebutuhan belajar semua anak, pemuda dan orang dewasa dengan fokus khusus pada mereka yang termarjinalisasikan dan tersisihkan. Dari tahun ke tahun, jumlah yang termarjinalisasikan dan tersisihkan ternyata tidak berkurang, bahkan terus bertambah. Pada tahun 2000 diperkirakan ada sekitar 113 juta anak usia sekolah dasar yang tidak masuk sekolah, $90 \%$ dari mereka hidup di negara-negara dengan pendapatan rendah dan menengah rendah dan lebih dari 80 juta anak tinggal di Afrika (UNESCO, 2003).

Pendidikan inklusi adalah sebuah proses yang memusatkan perhatian pada dan merespon keanekaragaman kebutuhan semua peserta didik melalui partisipasi dalam belajar, budaya dan komunitas, dan mengurangi ekslusi dalam dan dari pendidikan (UNESCO, 2003). Pendidikan inklusi mengakomodasi semua peserta didik tanpa mempertimbangkan kondisi fisik, intelektual, sosial, emosional, linguistik mereka dan kondisi lainnya. Ini berarti mencakup anak yang cacat dan berbakat, anak jalanan dan yang bekerja, anak dari penduduk terpencil dan nomadik (berpindah-pindah), anak dari kelompok minoritas bahasa, etnis atau budaya, dan anak dari kelompok atau wilayah yang termarjinalisasikan lainnya. Sekolah reguler dengan orientasi inklusi merupakan sarana yang sangat efektif untuk memberantas diskriminasi, menciptakan masyarakat yang hangat relasinya, membangun masyarakat 
inklusif, dan mensukseskan pendidikan untuk semua (UNESCO, 1994; UNESCO, 2003). Pendidikan inklusi bertujuan memungkinkan guru dan peserta didik merasa nyaman dalam keragaman, dan memandang keragaman bukan sebagai masalah, namun sebagai tantangan dan pengayaan bagi lingkungan belajar (UNESCO, 2003).

Semua karakteristik pendidikan inklusi di atas berimplikasi pada perubahan dan modifikasi pada materi, pendekatan, struktur dan strategi, dengan suatu visi umum yang mengkover semua peserta didik dan suatu pengakuan atau kesadaran bahwa menjadi tanggung jawab sistem reguler untuk mendidik semua peserta didik (UNESCO, 2003).

Pendidikan inklusi adalah hak asasi manusia, di samping merupakan pendidikan yang baik dan dapat menumbuhkan rasa sosial. Itulah ungkapan yang dipakai untuk menggambarkan pentingnya pendidikan inklusi. Ada beberapa argumen di balik pernyataan bahwa pendidikan inklusi merupakan hak asasi manusia: (1) semua anak memiliki hak untuk belajar bersama; (2) anak-anak seharusnya tidak dihargai dan didiskriminasikan dengan cara dikeluarkan atau disisihkan hanya karena kesulitan belajar dan ketidakmampuan mereka; (3) orang dewasa yang cacat, yang menggambarkan diri mereka sendiri sebagai pengawas sekolah khusus, menghendaki akhir dari segregrasi (pemisahan sosial) yang terjadi selama ini; (4) tidak ada alasan yang sah untuk memisahkan anak dari pendidikan mereka, anak-anak milik bersama dengan kelebihan dan kemanfaat untuk setiap orang, dan mereka tidak butuh dilindungi satu sama lain (CSIE, 2005).

Adapun alasan-alasan di balik pernyataan bahwa pendidikan inklusi adalah pendidikan yang baik: (1) penelitian menunjukkan bahwa anak-anak akan bekerja lebih baik, baik secara akademik maupun sosial, dalam setting yang inklusif; (2) tidak ada pengajaran atau pengasuhan dalam sekolah yang terpisah atau khusus yang tidak dapat terjadi dalam sekolah biasa; (3) dengan diberi komitmen dan dukungan, pendidikan inklusif merupakan suatu penggunaan sumber-sumber pendidikan yang lebih efektif. Dan argumen-argumen dibalik pernyataan bahwa pendidikan inklusi dapat membangun rasa sosial: (1) segregasi (pemisahan sosial) mendidik anak menjadi takut, bodoh, dan menumbuhkan prasangka; (2) semua anak membutuhkan suatu pendidikan yang akan membantu mereka mengembangkan relasi-relasi dan menyiapkan mereka untuk hidup dalam arus utama; dan (3) hanya inklusi yang berpotensi untuk mengurangi ketakutan dan membangun persahabatan, penghargaan dan pengertian (CSIE, 2005).

Pertimbangan filosofis yang menjadi basis pendidikan inklusi paling tidak ada tiga. Pertama, cara memandang hambatan tidak lagi dari perspektif peserta didik, namun dari perspektif lingkungan sekolah. Lingkungan sekolah harus memainkan peran sentral dalam transformasi 
hambatan-hambatan peserta didik. Kedua, perspektif holistik dalam memandang peserta didik. Dengan perspektif tersebut, peserta didik dipandang mampu dan kreatif secara potensial. Sekolah bertanggung jawab untuk menciptakan lingkungan di mana potensi-potensi tersebut berkembang. Ketiga, prinsip non-segregasi. Dengan prinsip ini, sekolah memberikan pemenuhan kebutuhan kepada semua peserta didik. Organisasi dan alokasi sumber harus cukup fleksibel dalam memberikan dukungan yang dibutuhkan kelas. Masalah yang dihadapi peserta didik harus didiskusikan terus menerus di antara staf sekolah, agar dipecahkan sedini mungkin untuk mencegah munculnya masalah-masalah lain (UNESCO, 2003).

Ada tiga langkah penting menuju inklusi yang nyata: komunitas, persamaan dan partisipasi. Semua staf yang terlibat dalam pendidikan merupakan suatu komunitas yang memiliki visi dan pemahaman yang sama tentang pendidikan inklusi, baik konsep dan pentingnya maupun dasar-dasar filosofis. Setiap anggota komunitas memiliki persamaan (hak yang sama), mereka sama-sama berpartisipasi dalam mengembangkan pendidikan inklusi, sejak dari perencanaan, pelaksanaan sampai evaluasinya. Dalam pendidikan inklusi, sistem sekolah tidak berhak menentukan tipe peserta didik, namun sebaliknya sistem sekolah yang harus menyesuaikan untuk memenuhi kebutuhan semua peserta didik. Terkait dengan ini, ada ungkapan bahwa komunitas (semua staf yang terlibat dalam pendidikan inklusi) 'melampaui dan di atas' (over and above) kurikulum (UNESCO, 2003).

\section{Madrasah Sebagai Sekolah Islami dan Pelaksana Pendidikan Inklusi}

Dengan salah satu keunggulan, madrasah sebagai sekolah islam yang benar-benar islami yang mampu memadukan kekuatan Ilmu Pengetahuan dan Teknologi (IPTEK) dan Iman dan Takwa (IMTAK), antara daya pikir dan dzikir, dan memiliki nilai lebih yang terletak pada pendidikan keimanan dan menekankan pada kepekaan hati serta ketajaman akal, maka inovasi kurikulum yang berorientasi kepada pendidikan yang ramah kepada semua anak di bawah naungan ketauhidan dan tidak mendikhotomikan antara ilmu dan agama dirasa sangat perlu dikembangkan. Ini semua dilakukan sebagai bentuk pemecahan terhadap kritik yang sering ditujukan kepada dunia pendidikan selama ini, yaitu pendidikan sekolah yang prosesnya diibaratkan penjara yang membatasi bahkan menghalangi perkembangan fitrah dan kreativitas anak dan produknya yang cenderung sekularistik.

Dalam kesempatan ini, keberadaan dan potensi madrasah sebagai sekolah Islam yang harus benar-benar islami akan dikaji dalam perspektif pendidikan Islam dan pendidikan inklusi sebagaimana yang telah dijelaskan di muka. Kajian dapat berbentuk evaluasi-kritis atau normatifdireksional. Kajian evaluasi-kritis memerlukan prasyarat berupa 
pengetahuan yang memadai tentang objek kajian, yaitu madrasah sebagai sekolah yang benar-benar islami. Namun, karena keterbatasan informasi tentang hal tersebut, hanya sedikit dari uraian berikut yang bersifat evaluasi-kritis. Selebihnya lebih bersifat normatif-direksional, memuat rambu-rambu atau tantangan yang terlahir dari gambaran bagaimana konsep pendidikan Islam dan konsep pendidikan inklusi yang dapat menjadi arah atau pedoman dalam mengembangkan program madrasah sebagai sekolah yang benar-benar islami. Namun, mendahului uraian tersebut akan dikaji terlebih dahulu kemungkinan titik singgung antara pendidikan Islam dan pendidikan inklusi.

\section{Titik Singgung Pendidikan Islam dan Pendidikan Inklusi}

Terdapat beberapa titik singgung yang dapat teridentifikasi. Pertama, pendidikan sebagai kewajiban/hak. Dalam perspektif Islam pendidikan merupakan kewajiban prasyarat, baik untuk memahami kewajiban Islam yang lain maupun untuk membangun kebudayaan/peradaban, sementara dalam perspektif inklusi pendidikan merupakan hak asasi manusia. Pernyataan pendidikan sebagai hak atau kewajiban bukan sesuatu yang perlu diperdebatkan karena perbedaan hanya terletak pada sudut pandang terhadap substansi yang sama: 'pendidikan sebagai hak' lebih antroposentris dan 'pendidikan sebagai kewajiban' lebih teosentris. Kedua, prinsip pendidikan untuk semua. Titik singgung kedua ini merupakan implikasi dari titik singgung pertama. Pendidikan inklusi, seperti telah dijelaskan, merupakan implikasi dari prinsip 'pendidikan sebagai hak asasi manusia' yang penerjemahannya dalam kebijakan global 1990 menjadi 'pendidikan untuk semua', sementara pendidikan Islam secara historis di masa peradaban klasik telah memfasilitasi lingkungan yang kondusif bagi 'pendidikan untuk semua' melalui pembentukan tradisi melek huruf. Ketiga, prinsip non-segregasi. Titik singgung ketiga ini merupakan implikasi lain dari titik singgung pertama. Dengan memandang pendidikan sebagai kewajiban/hak asasi manusia, maka setiap manusia tidak boleh termarjinalisasikan dan tersisih dalam memperoleh layanan pendidikan. Keempat, perspektif holistik dalam memandang peserta didik. Baik pendidikan Islam maupun pendidikan inklusi berupaya menumbuh-kembangkan kepribadian manusia dengan mengakui segenap daya dan potensi yang dimiliki peserta didik. Kelima, cara memandang hambatan yang lebih berorientasi pada faktor eksternal. Titik singgung kelima ini implikasi dari titik singgung keempat dan pertama. Karena segenap daya dan potensi peserta didik wajib atau berhak ditumbuh-kembangkan, maka faktor eksternal (lingkungan sekolah) harus memainkan peran sentral dalam transformasi hambatan-hambatan peserta didik. Hambatan belajar tidak lagi terletak pada diri peserta didik. 


\section{Bagaimana Madrasah Seharusnya dalam Perspektif Pendidikan Islam}

Bila madrasah mengemban sekolah yang islami maka bentuk inovasi kurikulum yang berorientasi kepada pendidikan yang ramah kepada semua anak di bawah naungan ketauhidan yang senantiasa mengintegrasikan antara ilmu dan agama, maka madrasah yang seperti ini dapat dipandang sebagai terapan dari prinsip non-segregasi dan perspektif holistik dalam memandang peserta didik. Terapan prinsip non-segregasi dapat dilihat dalam proses pendidikan yang ramah kepada semua anak. Adapun terapan yang menonjol dari perspektif holistik sekaligus menjadi faktor pembeda dari inovasi-inovasi pendidikan Islam Indonesia yang belakangan ini terjadi, adalah rancangan yang sengaja untuk mempertemukan daya nalar dan daya dzikr peserta didik dalam proses pembelajaran. Inovasi yang dilakukan tidak sekadar menambah pelajaran agama baik dalam bentuk kurikulum formal (penambahan sejumlah mata pelajaran agama) maupun kegiatan ko-kurikuler (seperti menghafal suratsurat pendek dalam Al-Qur'an dan shalat berjamaah) dan ekstra kurikuler yang tetap tidak terintegrasi dengan mata pelajaran umum, sebagaimana terjadi pada inovasi pendidikan melalui sekolah-islam terpadu yang 'fullday', namun betul-betul mencoba mengintegrasikan ayat-ayat qauliyah (yang bersumber dari Al-Qur'an dan atau Sunnah) dan ayat-ayat kauniyah (materi-materi ilmu pengetahuan alam [IPA] atau ilmu pengetahuan sosial [IPS]). Setiap paket pembelajaran dalam mata pelajaran IPA, misalnya, akan didahului kajian tentang ayat qauliyah sebelum kemudian masuk dalam kajian tentang ayat kauniyah. Secara implisit, inovasi ini telah mengangkat sesuatu yang selama ini termarjinalisasikan atau tersisih dalam praktik dunia pendidikan, yaitu ayat qauliyah baik sebagai nilai maupun sebagai data awal. Inovasi kurikulum madrasah yang seperti ini akan mengintegrasikan data dari ayat qauliyah dengan temuan-temuan keilmuan yang telah diperoleh dari ayat kauniyah, dan lebih dari itu mengintegrasikan pengetahuan dengan nilai-nilai ketauhidan.

Untuk ke depan, sebagai tantangan bagi pengembangan kurikulum madrasah sebagai sekolah islami, integrasi pengetahuan dan nilai tidak berhenti pada dimensi ta 'îm saja (pembelajaran kognitif), tetapi berlanjut pada dimensi tarbiyah (pendidikan moral) dan ta'dîb (pendidikan estetik dan spiritual) integrasi pengetahuan dan nilai (nalar dan iman) yang memperkuat spirit penelitian dan pengembangan yang terbuka, dan mengantarkan peserta didik menuju pengetahuan yang tinggi, kemampuan yang produktif, perilaku yang bermoral dan estetik, pilihan hidup individual yang logis dan sehat, dan kewarganegaraan yang bertanggung jawab.

Tantangan lain yang perlu didiskusikan bersama adalah penerapan prinsip 'pendidikan sebagai kewajiban kemanusiaan' atau prinsip 
'pendidikan untuk semua' dalam rekrutmen calon peserta didik (siswa). Karena, bisa saja dalam praktik rekrutmen siswa baru, yang terjadi adalah penerimaan siswa-siswa pilihan atau unggul saja apa pun kriteria yang dipakai. Kalau ini terjadi, akan ada calon-calon siswa yang termarjinalisasikan dan tersisih. Bukankah ini berlawanan dengan prinsip 'pendidikan sebagai kewajiban kemanusiaan' atau prinsip 'pendidikan untuk semua'?

Tantangan yang tidak kalah penting untuk diantisipasi adalah operasionalisasi cara memandang hambatan yang lebih berorientasi pada faktor eksternal. Bila lingkungan sekolah harus memainkan peran sentral dalam transformasi hambatan-hambatan peserta didik, maka akan banyak terjadi perubahan, tidak hanya sekedar modifikasidalam materi, pendekatan, struktur dan strategi. Perubahan dalam materi (bahan belajar) telah dilakukan, sementara kebijakan untuk menciptakan lingkungan pembelajaran yang ramah untuk semua peserta didik dapat dipandang sebagai langkah awal antisipasi yang tepat. Praktik dari kebijakan itu, seperti fleksibilitas guru dalam strategi pembelajaran dan perlakuan terhadap siswa, memerlukan ruang tidak saja diskusi tetapi juga terapannya dalam arti yang sebenarnya karena berhadapan dengan kondisi budaya selama ini yang terkesan lebih memenjarakan potensi dan kreativitas siswa.

\section{3. "Madrasah sebagai sekolah yang Islami" dan Perspektif Pendidikan Inklusi.}

Secara evaluatif, dapatlah dikatakan bahwa kurikulum madrasah sebagai sekolah yang islami seharusnya menciptakan lingkungan pendidikan dan pembelajaran yang ramah untuk semua peserta didik. Ini sebagai wujud terapan dari beberapa prinsip pendidikan inklusi, yaitu prinsip non-segregasi dan prinsip perspektif holistik dalam memandang peserta didik. Dengan lingkungan yang ramah, setiap peserta didik diakui sesuai dengan daya dan potensinya dan memperoleh layanan pendidikan tanpa perbedaan, disesuaikan dengan daya dan potensinya tersebut.

Tentang tantangan ke depan yang segera harus disiapkan, karena ada beberapa titik singgung antara pendidikan Islam dan pendidikan inklusi adalah beberapa prinsip atau norma pendidikan inklusi yang sebelumnya telah dibicarakan dalam kajian di atas tentang madrasah sebagai sekolah yang islami dari perspektif pendidikan Islam, seperti operasionalisasi cara memandang hambatan yang lebih berorientasi pada faktor eksternal yang menuntut secara normatif-direksional peran sentral madrasah dalam transformasi hambatan-hambatan peserta didik, dan berimplikasi pada fleksibilitas kurikulum, termasuk strategi pembelajarannya. Selain itu, yang tidak kalah pentingnya adalah membangun komunitas pendukung yang melibatkan semua staf pendidikan, memiliki persamaan hak, karena kesemuanya berpartisipasi 
dalam mengembangkan pendidikan inklusi, sejak dari perencanaan, pelaksanaan sampai evaluasinya. Hal ini sangat perlu ditekankan karena komunitas, persamaan, dan partisipasi merupakan norma-norma direksional menuju inklusi yang nyata.

Terkait dengan prinsip 'pendidikan sebagai hak asasi manusia' atau 'pendidikan untuk semua', tantangan ke depan yang harus di antisipasi adalah mengembangkan madrasah sesuai norma 'pendidikan inklusi' yang mengakomodasi semua peserta didik tanpa mempertimbangkan kondisi fisik, intelektual, sosial, emosional, linguistik mereka dan kondisi lainnya. Ini berarti mencakup anak yang cacat dan berbakat, anak jalanan dan yang bekerja, anak dari penduduk terpencil dan nomadik (berpindah-pindah), anak dari kelompok minoritas bahasa, etnis atau budaya, dan anak dari kelompok atau wilayah yang termarjinalisasikan lainnya.

\section{E. Kesimpulan}

Demikianlah, beberapa hal yang seharusnya dilakukan mengembangkan madrasah yang bebar-benar islami dengan segala keterbatasannya. Objektivitas kajian telah diusahakan melalui prinsip normatif pendidikan Islam dan pendidikan inklusi, sehingga bila ada kesesuaian dengan harapan dalam mengembangkan program madrasah yang islami sesuai prinsip normatif pendidikan Islam atau pendidikan inklusi, maka hal itu tidak dimaksudkan untuk legitimasi. Dan memang, yang lebih banyak adalah tawaran tantangan ke depan yang perlu diantisipasi dan dipersiapkan dalam mengembangkan kurikulum madrasah yang islami. Wallâhu a lam bish-shawâb.

\section{F. DAFTAR PUSTAKA}

al-Attas, Syed Muhammad al-Naquib (ed.) (1979), Aims and Objectives of Islamic Education. Jeddah: King Abdulaziz University dan Hodder \& Stoughton.

Ashraf, Syed Ali (1985), New Horizon in Muslim Education. Chippenham: Hodder \& Stoughton.

CSIE (Centre for Studies on Inclusive Education) (2005), Ten Reasons for Inclusion, http://inclusion.uwe.ac.uk/ csie/10rsns.htm.

Douglass, Susan L. dan Shaikh, Munir A. (2004), 'Defining Islamic Education: Differentation and Aplications' dalam CICE (Current Issues in Comparative Education) Journal: Islam and Education, Vol. 7, No. 1, December 15.

Duri, A. A. (1983), The Rise of Historical Writing among the Arabs, terjemahan L. I. Conrad. Princeton: Princeton University Press.

Hassan, A. Y. \& Hill, D. (1986), Islamic Technology. Cambridge : Cambridge University Press. 
A. Abtokhi-Madrasah Sebagai Sekolah Islami

Khoiri, M.(2004). Kepemimpinan Kepala Madrasah Dalam Mengembangkan Madrasah Unggulan, Thesis, Pasca Sarjana, UNISMA, Malang.

Ould Bah, M. (1998), Islamic Education between Tradition \& Modernity. Morocco: ISESCO.

Program Al-Qur'an dan Terjemahnya. WordQur'an.

Sahadat, John (1997), 'Islamic Education: a Challenge to Conscience' dalam The American Journal of Islamic Social Sciences, Vol. 14, No. 4 (Winter).

Santoso, M.A. Fattah (1992), 'Ilmu Pengetahuan dalam Pandangan Islam' dalam Akademika, Tahun X, No. 1.

Sardar, Ziauddin dan Malik, Zafar Abbas (1997), Mengenal Islam for Beginners, terjemahan Qowayfa. Bandung: Mizan.

Sarwar, G. (1996), 'Islamic Education: its Meaning, Problems and Prospects' dalam Issues in Islamic Education. London : The Muslim Educational Trust.

UNESCO (1990), World Declaration on Education for All and Framework for Action to Meet Basic Learning Needs. International Consultative Forum on Education for All. Paris: UNESCO.

UNESCO (1994), The Salamanca Statement and Framework for Action on Special Needs Education, World Conference on Special Needs Education: Access and Quality. Paris: UNESCO and the Ministry of Education, Spain. Versi pdf., http:// portal.unesco.org/education/en/ev.php.

UNESCO (2003), Conseptual Paper: UNESCO Inclusive Education, a Challenge and a Vision. http:// portal.unesco.org/education/en/ev.php. 
A. Abtokhi-Madrasah Sebagai Sekolah Islami

Madrasah, Vol. 1 No. 1 Juli-Desember 2008 